\title{
Analisis Sentimen New Normal Pada Masa Covid-19 Menggunakan Algoritma Naïve Bayes
}

\author{
Shania Gabriela Kaparang ${ }^{1}$, Daniel R. Kaparang ${ }^{2}$, Vivi P. Rantung ${ }^{3}$ \\ Program Studi Teknik Informatika UNIMA \\ kaparangshania@gmail.com
}

\begin{abstract}
The impact of the covid-19 pandemic is so great that the government must have policies to reduce its impact. One of the government's policies is the new normal which requires all people to wear masks, keep their distance and wash their hands. In its application, of course, there are positive and negative sentiments uploaded to Twitter. This study aims to model the analysis of public sentiment regarding the government's new normal policy during the covid-19 pandemic in Indonesia. The stages of this research are data crawling, labeling, neutral data removal, preprocessing, distribution of training data and data testing, creation of a nave Bayes classification system, system testing and visualization of research results using wordcloud. The classification system performance includes $80.37 \%$ accuracy, $\mathbf{8 7 . 3 8 \%}$ precision, $82.57 \%$ recall and $84.91 \%$ f-measure. The results of this study are 5194 tweets classified as positive sentiment and 2908 tweets classified as negative sentiment, this shows that there are more positive sentiments than negative sentiments. But from the numbers it can be seen that the comparison is not too far between positive and negative sentiments, meaning that there is a lack of public response to the new normal government policies during the pandemic.
\end{abstract}

Keywords - sentiment analysis, new normal, naïve bayes classifier.

\begin{abstract}
Abstrak - Dampak dari pandemi covid-19 begitu besar sehingga pemerintah harus memiliki kebijakan agar dapat mengurangi dampaknya. Salah satu kebijakan pemerintah yaitu new normal yang mewajibkan seluruh masyarakat untuk pakai masker, jaga jarak dan cuci tangan. Dalam penerapannya tentu ada sentimen-sentimen baik positif maupun negatif yang diunggah ke dalam

Twitter. Penelitian ini bertujuan untuk membuat pemodelan analisis sentimen masyarakat mengenai kebijakan new normal pemerintah pada masa pandemi covid-19 di Indonesia. Tahapan penelitian ini yakni crawling data, labeling, penghapusan data netral, preprocessing, pembagian training data dan testing data, pembuatan sistem klasifikasi naïve bayes, uji coba sistem dan visualisasi hasil penelitian dengan menggunakan wordcloud. Performa sistem klasifikasinya antara lain, tingkat akurasi $80,37 \%$, presisi 87,38\%, recall $82,57 \%$ dan $f$-measure $84,91 \%$. Hasil dari penelitian ini yaitu 5194 tweets terklasifikasi sentimen positif dan 2908 tweets terklasifikasi sentiment negative, hal ini menunjukkan bahwa sentimen positif lebih banyak daripada sentimen negatif. Tetapi dari jumlahnya bisa dilihat bahwa perbandingannya tidak terlalu jauh antara sentimen positif dan sentimen negatif, artinya ada respon masyarakat yang masih kurang terhadap kebijakan pemerintah new normal pada masa pandemi.
\end{abstract}

Kata Kunci- analisis sentimen, new normal, naïve bayes classifier.

\section{PENDAhUluan}

Dunia saat ini digemparkan dengan keberadaan virus yang menyerang organ pernafasan manusia. Virus corona adalah penyakit yang bisa menyerang siapa saja dan negara mana saja di dunia. Tercatat lebih dari 114 negara telah terinfeksi dan menimbulkan korban meninggal yang cukup besar.[1] Pandemi corona ini masih berlangsung di berbagai negara di dunia, termasuk Indonesia. Jika sebelumnya Indonesia belum terdeteksi kasus virus corona hingga akhir Februari, kini Indonesia menjadi salah satu negara yang terkena virus ini. Pada 2 Maret 2020, Presiden Jokowi akhirnya mengumumkan kasus covid-19 pertama di Indonesia.[2]

Pada akhir bulan Mei 2020 Pemerintah telah menetapkan kebijakan new normal atau kebiasaan baru yang akan dilakukan secara bertahap. Pembatasan-pembatasan yang ditetapkan yaitu kantor/perusahaan, rumah makan, bioskop, rumah sakit, pariwisata, transportasi dan sektor lainnya. Kebijakan yang paling ramai disosialisasikan bahkan sampai saat ini yaitu 3M (menjaga jarak, memakai masker dan mencuci tangan). 3M ini tentunya diperuntukkan untuk semua kalangan tanpa terkecuali, termasuk bagi pemerintah sendiri yang menyusun kebijakan tersebut. Namun seiring berjalannya new normal, masih ada masyarakat bahkan pemerintah yang masih mengabaikan $3 \mathrm{M}$ ini. Tindakan mereka tentu disoroti oleh para pengguna sosial media khususnya Twitter. Ada banyak tweets/cuitan baik 2 dalam bentuk positif, negatif maupun netral. Diantaranya, tweet positif yang mengajak masyarakat untuk taat pada protokol kesehatan: "Mari Disiplin pakai masker dan cuci tangan menggunakan sabun dan air mengalir, jangan biarkan Virus covid 19 menempel di tubuh Anda https://t.co/CxptQpYGU9” Adapun tweet negatifnya, “@AdityaPrtmR@surethingCB@tanyainrl tapi sejauh ini yang suka nongki2 ga jelas beneran udah nerapin prokes? jarang cuyyy, nongkrong rame 2 ga pake masker gaada jaga jarak, toh apa susahnya juga diem2 dirumah". Di dalam penelitian ini, peneliti menggunakan text mining pengklasifikasian opini berupa analisis teks sentimen pada Twitter terkait new normal pada masa covid-19 di Indonesia 
yang akan menghasilkan data analisis opini publik (positif maupun negatif).

\section{TINJAUAN PUSTAKA}

\section{A. Text Mining}

Text mining merupakan salah satu teknik klasifikasi yang dapat digunakan dalam menggali informasi dari suatu rangkaian teks yang terdapat dalam sebuah dokumen.

Text mining merupakan variasi dari data mining yang berusaha menemukan pola yang menarik dari sekumpulan data tekstual yang berjumlah besar. Text mining bisa disebut juga dengan penemuan informasi yang sebelumnya oleh komputer tidak diketahui dan baru diketahui, mengekstrak informasi secara otomatis dari berbagai sumber yang berbeda. Kunci dari proses text mining yakni menggabungkan informasi yang telah berhasil diekstraksi dari berbagai sumber.[3]

Jadi text mining dalam kaitannya dengan analisis sentiment dapat didefinisikan sebagai data dalam bentuk teks yang biasanya didapatkan dari suatu dokumen, yang bertujuan mencari teks atau kata yang menggambarkan maksud dari dokumen tersebut yang selanjutnya dilakukanlah analisa keterkaitan antar dokumen.

\section{B. Analisis Sentimen}

Menurut Nasukawa dan Yi, analisis sentimen adalah cara yang digunakan untuk mengidentifikasi sentimen berupa teks dan mengkategorikan sentimen tersebut sebagai sentimen positif maupun sentimen negatif.[4]

Analisis sentimen dapat memberikan informasi kritis tentang persepsi risiko masyarakat. Pendekatan perhitungan menganalisis data tekstual untuk menafsirkan dan mengklasifikasikan emosi publik terhadap masalah apapun yang diberikan (misalnya. produk, peraturan, ukuran, dll)[5]

Di era media sosial, analisis sentimen dapat secara efisien menganalisis data yang jumlahnya berlebihan, yang sebagian besar bersifat pribadi, dapat diakses dan dianalisis dengan bebas. Faktanya, Twitter telah digunakan secara luas untuk pengawasan kesehatan masyarakat, dari pemantauan dan prediksi untuk mengukur respon publik.[6]

Jadi dapat diartikan analisis sentimen adalah sebuah proses klasifikasi kata/teks untuk mengkategorikan pendapat atau opini orang apakah termasuk dalam kategori positif atau negatif.

\section{Covid-19}

Berdasarkan Groot,dkk dalam "Ninth Report of the International Committee on Taxonomy of Viruses" penyakit Coronavirus 2019 (COVID-19) adalah penyakit menular yang disebabkan oleh sindroma pernafasan akut yaitu Coronavirus 2 (SARS-CoV-2). SARS-CoV-2 dikenal sebagai subfamily Orthocoronavirinae, family Coronaviridae, order Nidovirales, dan realm Riboviria. Corona virus adalah sekelompok virus terkait yang menyebabkan penyakit pada mamalia dan burung. Pada manusia, corona virus menyebabkan infeksi saluran pernapasan yang dapat berkisar dari ringan sampai mematikan. Penyakit ringan mencakup beberapa kasus selesma, sedangkan varietas yang lebih mematikan dapat menyebabkan SARS, MERS, dan COVID-19. Belum ada vaksin atau obat anti virus untuk mencegah atau mengobati infeksi corona virus manusia.[7]

\section{New Normal}

Menurut Yuri, tatanan, kebiasaan dan perilaku yang baru berbasis pada adaptasi untuk membudayakan perilaku hidup bersih dan sehat inilah yang kemudian disebut sebagai new normal. Cara yang dilakukan dengan rutin cuci tangan pakai sabun, pakai masker saat keluar rumah, jaga jarak aman dan menghindari kerumunan. Pihaknya berharap kebiasaan baru ini harus menjadi kesadaran kolektif agar dapat berjalan dengan baik.[8]

\section{E. Twitter}

Twitter merupakan salah satu media sosial yang sering digunakan untuk berbagi pesan teks, foto, video, berita, informasi dll. Dari artikel yang diterbitkan Kominfo, pengguna Twitter, berdasarkan data PT Bakrie Telecom, memiliki 19,5 juta pengguna di Indonesia dari total 500 juta pengguna global. Twitter menjadi salah satu jejaring sosial paling besar di dunia sehingga mampu meraup keuntungan mencapai USD 145 juta. Kebanyakan pengguna Twitter di Indonesia adalah konsumen, yaitu yang tidak memiliki Blog atau tidak pernah mengupload video di Youtube namun sering update status di Twitter dan Facebook.[9]

Beberapa istilah yang sering digunakan dalam Twitter:

1. Mention adalah suatu cara untuk membuat link terhadap akun Twitter atau menyebut akun pengguna lain. Mention memiliki simbol '@' lalu disertai nama akun Twitter yang dipanggil. Biasanya mention digunakan untuk membalas tweet atau ingin menandai ke akun pengguna lain.

2. Hashtag memiliki symbol "\#” yang digunakan untuk mengindeks sebuah topik atau isu pembicaraan di Twitter agar pengguna dapat menemukan topik yang mereka inginkan dengan mudah. Hashtag juga bisa digunakan agar orang lain dapat dengan cepat menemukan tweet dari pengguna tersebut.

3. Emoticon, dahulu penggunaan emoticon di Twitter hanya berupa kombinasi huruf, angka atau tanda baca, namun emoticon sekarang sudah diperbaiki dan dalam bentuk gambar. Biasanya penggunaan emoticon untuk mengekspresikan perasaan dari pengguna.

4. Trending topic adalah tagar yang ramai dibahas dalam satu waktu di Twitter. Dimana kita bisa melihat isu yang ramai dibicarakan atau dibahas pada saat itu.[10]

Jadi dapat diartikan Twitter menjadi tempat atau media bagi para penggunanya untuk menyalurkan dan mengekspresikan apa yang mereka rasakan, alami, dan juga bisa membentuk sebuah percakapan dengan pengguna lain serta memberikan respon terhadap apa yang dunia sedang dialami melalui suatu peristiwa ataupun fenomena yang sementara terjadi.

\section{F. Nä̈ve Bayes Classifier}

Suatu algoritma yang sering dipakai untuk keperluan data mining karena memudahkan penggunaannya, waktu pemrosesan yang cepat, mudah diterapkan dengan bentuknya yang cukup sederhana dengan tingkat efektifitas yang tinggi adalah naive bayes classifier.[11] 
Secara sederhana naive bayes classifier menunjukkan bahwa ada bahkan tidak adanya sebuah fitur dalam sebuah kelas tidak berpengaruh dengan ada maupun tidak adanya fitur lainnya. Misalnya, sesuatu yang tampak bulat, berwarna orange dan berdiameter sekitar $11 \mathrm{~cm}$ dapat diklasifikasikan sebagai buah jeruk. Meskipun fitur ini saling berkaitan antara satu dengan yang lain, naive bayes classifier akan tetap menganggap bahwa fitur-fitur tersebut mandiri dan tidak saling mempengaruhi.[12]

\section{MetodE}

Berikut adalah alur diagram metodologi penelitian:

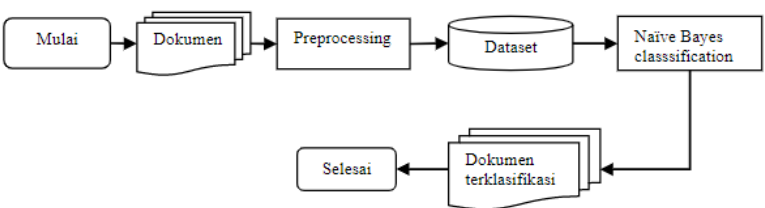

Gbr. 1 Flowchart Metodologi Penelitian

\section{A. Teknik Pengumpulan Data}

Tahap pertama yang dilakukan dalam analisis sentimen adalah pengumpulan data. Data di ambil dari media sosial Twitter. Twitter mempermudah para pengembang dengan menyediakan API (Application Programming Interface) dalam pengambilan data.

Selanjutnya, setelah menjadi sebuah dataset dari data yang telah berhasil dikumpulkan, data tersebut kemudian diberi label (pelabelan). Pelabelan di sini bertujuan untuk membagi data yang telah diberi label ke dalam kelas-kelas sentimen dan akan digunakan dalam penelitian. Kebanyakan kelas sentimen yang digunakan adalah negatif, netral dan positif. Proses pelabelan ditujukan untuk membagi 2 bagian dari dataset, yaitu training data dan testing data. Training data adalah data yang dipakai untuk melatih sebuah sistem supaya dapat mengenali pola yang sedang dicari, sedangkan data yang digunakan untuk menguji hasil pelatihan yang sudah dilakukan adalah testing data.

\section{B. Preprocessing}

Tahap selanjutnya setelah data diberi label adalah preprocessing. Pada tahap ini, data disiapkan untuk selanjutnya siap dilakukan analisis. Tahap-tahap dalam preprocessing ini, yaitu cleansing, case folding, stopwords dan tokenisasi. Di bawah ini adalah penjelasan secara rinci mengenai tahap preprocessing.

Cleansing, tahap di mana baik tanda baca maupun karakter yang tidak berpengaruh dalam penelitian dibersihkan dari teks tersebut. Karakter yang dibersihkan yakni tanda baca, situs url, dll.

Case Folding, proses mengubah semua huruf yang ada di dalam teks menjadi lower case.[13]

Stopwords, tahap menghilangkan kata-kata yang tidak bermakna dalam proses pengklasifikasian. Intinya, stop words list merupakan kumpulan kata-kata yang sering digunakan dalam berbagai bahasa. Penghapusan stop words dalam berbagai program aplikasi yang memiliki kaitan dengan text mining yaitu dikarenakan penggunaannya yang terlalu umum supaya pengguna bisa fokus pada kata-kata lain yang jauh lebih penting.[14]

Tokenisasi dilakukan untuk membagi kalimat dalam beberapa kata atau bagian. Hasil dari pembagian kata ini disebut token.[15]

\section{Pembobotan Kata}

Pembobotan kata merupakan sebuah mekanisme untuk memberikan nilai terhadap frekuensi kemunculan sebuah kata dalam dokumen teks. Metode pembobotan kata salah satunya adalah TF-IDF (Term Frequency-Inverse Document Frequency) yakni sebuah metode pembobotan penggabungan dua konsep, yaitu Term Frequency dan Document Frequency. [16] Term Frequency adalah konsep pembobotan dengan mencari frekuensi munculnya sebuah term dalam satu dokumen.[17] Karena setiap dokumen punya panjang yang berbeda, kemungkinan bisa terjadi di dokumen yang panjang muncul lebih banyak kata dibandingkan pada dokumen-dokumen yang pendek. Sehingga term frequency cenderung dibagi dengan jumlah kata yang ada dalam dokumen. Document Frequency merupakan banyaknya jumlah dokumen dimana sebuah term itu muncul. Nilai bobot yang semakin kecil merupakan akibat dari semakin kecil frekuensi kemunculannya. Dalam tahap perhitungan term frequency, semua kata akan dianggap sama pentingnya. Sebenarnya terdapat kata yang kurang penting dan tidak perlu diperhitungkan seperti "ter-", "di-", "ber-", "-kan" "dan" dan lain sebagainya. Karena itu, kata yang penting diberi bobot yang lebih besar sedangkan kata yang kurang penting dikurangi bobotnya. Inilah mengapa diperlukan stopword.

\section{Metode Nä̈ve Bayes Classifier}

Proses selanjutnya yaitu klasifikasi dengan menggunakan metode Nä̈ve Bayes. Dalam tahap ini dilakukan untuk membentuk model klasifikasi yang nantinya akan digunakan untuk mengklasifikasikan data uji $\mathrm{X}$ agar mendapat label $\mathrm{Y}$

Secara umum proses yang dilakukan dalam klasifikasi naïve bayes adalah:

- Mencari nilai peluang dari setiap kategori dokumen

- Mencari nilai peluang kemunculan dari masingmasing kata pada masing-masing kategori dokumen

- Menentukan kategori dokumen uji berdasarkan perhitungan dari proses pertama dan kedua.

- Perhitungan Performa Sistem

Setelah data uji selesai diklasifikasikan, maka dilakukan perhitungan performa sistem yang terdiri dari akurasi, presisi, recall dan $f$-measure dengan confusion matrix.[18] Algoritma dari metode Nä̈ve Bayes Classifier adalah sebagai berikut:

Pada tahap pembuatan sistem pengklasifikasi menggunakan Nä̈ve Bayes ada 2 tahap yang dilakukan. Pertama yaitu proses pelatihan data (training) dan tahap kedua adalah proses pengujian data (testing).[19]

1. Tahap Training (Pelatihan)

Langkah tahap training menggunakan NB adalah:

1) Menentukan probabilitas kategori dari data latih 
2) Menghitung probabilitas kata (TFIDF) dari data latih

3) Menghitung probabilitas untuk setiap kelas data latih

$$
P(w k)=\frac{p k+1}{n+|v o c a b|}
$$

Dimana:

$$
\mathrm{P}(\mathrm{wk}) \quad \text { : Probabilitas term }
$$

$\mathrm{Pk}+1 \quad$ : Query +1 agar hasil tidak nol

$\mathrm{n} \quad$ : jumlah kata yang muncul di outcomedok $|v o c a b|$ : total kata keseluruhan

2. Tahap Testing (Pengujian)

Langkah tahap testing menggunakan NB adalah:

1) Menemukan Vmap untuk setiap data uji

$$
V \operatorname{map}=P(w k \mid c) \cdot P(c)
$$

2) Menentukan Vmap maksimum

3) Diketahui model klasifikasinya

4) Diperoleh kelas prediksi

\section{HASIL DAN PEMBAHASAN}

Hasil dari penelitian ini menggunakan metode Nä̈ve Bayes Classifier dengan memanfaatkan software Data Mining yaitu Rapidminer, berikut adalah arsitektur sistemnya:

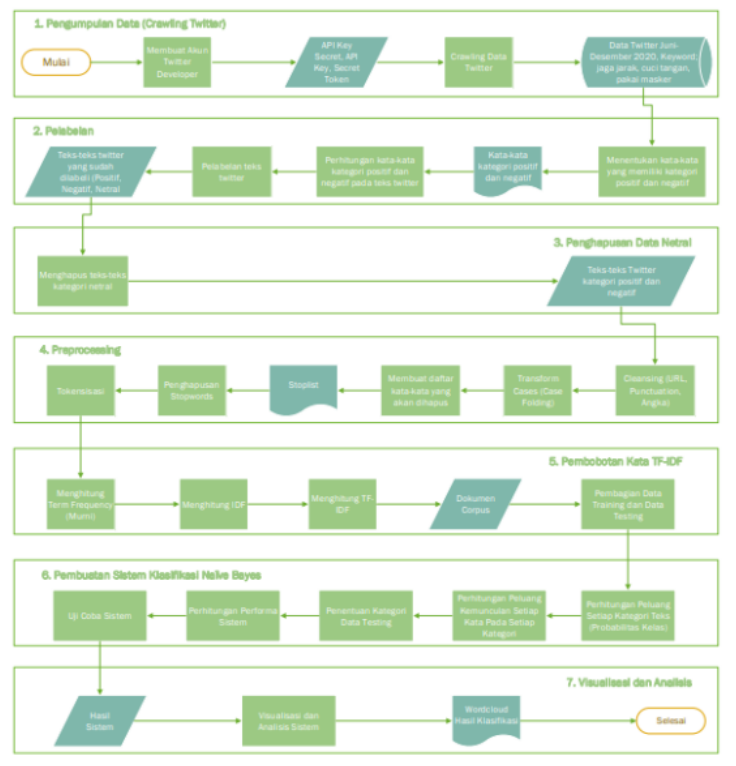

Gbr. 2 Arsistektur Sistem

\section{A. Mengambil Data dari Twitter (Crawling)}

Hal pertama yang harus dilakukan membuat akun Twitter Developer untuk mendapatkan API Key, API Key Secret dan Token Secret yang berguna saat pengambilan data Twitter (crawling).

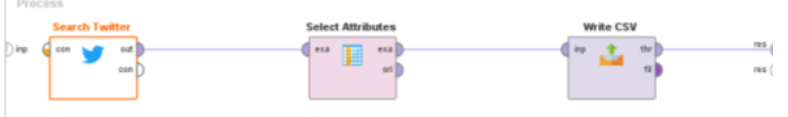

Gbr. 3 Proses Crawling Twitter

Data yang diambil adalah data Twitter yang diunggah mulai dari tanggal 1 Juni - 31 Desember 2020, dengan limit 10.000 data tweets. Keyword-nya yaitu jaga jarak, cuci tangan dan pakai masker.

\section{B. Seleksi dan Pelabelan Data}

Dari semua data Twitter yang berhasil di crawling, selanjutnya dilakukan pelabelan data karena hasil crawling merupakan data yang tidak diberi label (unsupervised data). Dikarenakan begitu banyak data yang harus diberi label maka dilakukan proses pelabelan dengan cara menentukan kata-kata yang memiliki arti positif dan negatif. Selanjutnya dihitung jumlah keseluruhan kata positif dan kata negatif yang ada pada teks. Pengklasifikasiannya, label 1 jika jumlah kata positif lebih besar dari kata negatif, label -1 jika jumlah kata negatif lebih besar dari kata positif, label 0 jika jumlah kata positif sama besar dengan jumlah kata negatif. Berikut adalah contoh kata-kata yang memiliki arti positif dan negatif.

TABEL I. KATA-KATA KATEGORI POSITIF DAN NEGATIF

\begin{tabular}{|c|c|}
\hline Positif & Negatif \\
\hline aman & tanpa \\
\hline merdeka & tidak \\
\hline patuh & mati \\
\hline rajin & kerumunan \\
\hline taat & kacau \\
\hline disiplin & menular \\
\hline tertib & melanggar \\
\hline rutin & batuk \\
\hline cegah & ramai \\
\hline ajak & meninggal \\
\hline
\end{tabular}

Berikut adalah contoh tweet yang sudah dikategorikan positif, negatif dan netral.

Tabel 2. Pelabelan Tweet Kategori Positif, Negatif dan Netral

\begin{tabular}{|l|c|c|c|}
\hline Tweet & Positif & Negatif & Label \\
\hline $\begin{array}{l}\text { Berbelanja dengan aman } \\
\text { pakai masker, jaga jarak } \\
\text { cuci tangan }\end{array}$ & 1 & 0 & Positif \\
\hline $\begin{array}{l}\text { Kerumunan di kalangan } \\
\text { merpati kolong jg tetap } \\
\text { ramai tanpa masker dan } \\
\text { tanpa jaga jarak. } \\
\text { Merdekanya warga } \\
\text { brebes, mati itu sdh takdir } \\
\text { dan pasti. masang } \\
\text { mustoko mushola jg rame } \\
\text { tanpa prokes, diarak } \\
\text { keliling kampung. Pakai }\end{array}$ & 1 & 5 & Negatif \\
\hline $\begin{array}{l}\text { Kapan Harus dalam } \\
\text { Masker di Infografis }\end{array}$ & 0 & 0 & Netral \\
$\begin{array}{l}\text { Ruangan? dengerin } \\
\text { https://t.co/ZXntUW11oc }\end{array}$ & & & \\
\hline $\begin{array}{l}\text { @tanyainrl siki cuci } \\
\text { lagu, sikat gigi, } \\
\text { tangan, cuci muka, sabun, } \\
\text { shampoo }\end{array}$ & 0 & 0 & $\begin{array}{c}\text { Netral } \\
\text { Outlier) }\end{array}$ \\
\hline
\end{tabular}

\section{Penghapusan Data Netral}

Penghapusan data netral dilakukan secara manual. Data netral dihapus karena nantinya akan mengganggu proses pengklasifikasian sesuai label kelas. Data netral berupa tweet yang masih menyangkut new normal yang ada di 
Indonesia tapi tidak memiliki sentimen positif dan negatif atau tidak memihak. Data netrral ini tidak diperlukan karena sesuai dengan penelitian ini yang diperlukan hanya data positif dan negatif. Selain itu pada data netral terklasifikasi juga di dalamnya yaitu data outlier, data yang tidak menyangkut New normal atau yang tidak menyangkut penelitian ini, tweet berbahasa inggris dll. Data yang tersisa setelah penghapusan data netral yaitu 816 data dengan data kategori positif sebanyak 546 dan data kategori negatif sebanyak 270.

D. Pembersihan (Cleansing)

Terdapat beberapa proses cleansing didalamnya, yang pertama yaitu cleansing URL.
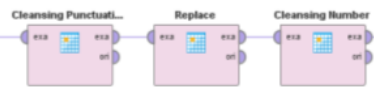

Gbr. 4 Cleansing URL

Dalam proses cleansing url ini semua tweet yang memiliki html atau url akan di hapus. Proses pembersihan ini dilakukan karena $\mathrm{html}$ atau $\mathrm{url}$ tidak akan digunakan dalam proses analisis sentimen dan tidak memiliki pengaruh apa-apa. Berikut adalah contoh sebelum dibersihkan dan sesudah melewati proses cleansing.

TABel 3. PerbedaAn Sebelum dan Sesudah Cleansing URL

\begin{tabular}{|l|l|}
\hline \multicolumn{1}{|c|}{ Sebelum cleansing url } & \multicolumn{1}{|c|}{ Setelah cleansing url } \\
\hline $\begin{array}{l}\text { Cegah Covid-19, Anggota } \\
\text { Polsek Laung Tuhup Ajak }\end{array}$ & $\begin{array}{l}\text { Cegah Covid-19, Anggota } \\
\text { Polsek Laung Tuhup Ajak } \\
\text { Warga Rajin Cuci Tangan } \\
\text { Warga Rajin Cuci Tangan } \\
\text { Depan Mako } \\
\text { https://t.co/HOm6oWzmeq }\end{array}$ \\
\hline $\begin{array}{l}\text { Tindak pelanggar Protokol } \\
\text { kesehatan tidak pakai } \\
\text { Masker } \\
\text { https://t.co/lw7VBv086k }\end{array}$ & $\begin{array}{l}\text { Tindak protokol kesehatan tidak } \\
\text { pakai Masker }\end{array}$ \\
\hline
\end{tabular}

Selain itu dilakukan juga pembersihan tanda baca dan angka. Berikut adalah sebelum dan sesudah cleansing tanda baca dan angka.

Tabel 4. PerbedaAn Sebelum Dan Sesudah Cleansing TANDA BACA DAN ANGKA

\begin{tabular}{|l|l|}
\hline $\begin{array}{c}\text { Sebelum cleansing tanda } \\
\text { baca\&angka }\end{array}$ & $\begin{array}{c}\text { Setelah cleansing tanda } \\
\text { baca\&angka }\end{array}$ \\
\hline $\begin{array}{l}\text { Cegah Covid-19, Anggota } \\
\text { Polsek Laung Tuhup Ajak }\end{array}$ & $\begin{array}{l}\text { Cegah Covid Anggota } \\
\text { Polsek Laung Tuhup } \\
\text { Warga Rajin Cuci Tangan } \\
\text { Ajak Warga Rajin Cuci } \\
\text { Tangan Depan Mako }\end{array}$ \\
Depan Mako & Tindak pelanggar \\
Tindak pelanggar Protokol \\
kesehatan tidak pakai \\
Masker
\end{tabular}

\section{E. Transform Cases (Case Folding)}

Tahap selanjutnya dalam preprocessing adalah transform cases atau sering disebut case folding yaitu proses mengubah semua huruf menjadi lower cases (huruf kecil).

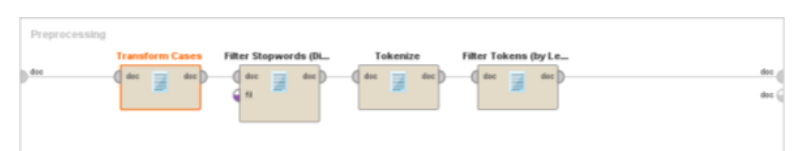

Gbr. 5 Sub-process Transform Cases (Case Folding)

Berikut adalah perubahan sebelum dan sesudah proses transform cases.

TABel 5. PerbedaAn SEbelum dan Sesudah Transform CaSeS

\begin{tabular}{|l|l|}
\hline Sebelum transform cases & \multicolumn{1}{|c|}{ Setelah transform cases } \\
\hline Cegah Covid-19, Anggota & cegah covid anggota \\
Polsek Laung Tuhup Ajak & polsek laung tuhup ajak \\
Warga Rajin Cuci Tangan & $\begin{array}{l}\text { warga rajin cuci tangan } \\
\text { depan mako }\end{array}$ \\
Depan Mako & $\begin{array}{l}\text { tindak pelanggar protokol } \\
\text { Tindak pelanggar Protokol } \\
\text { kesehatan tidak pakai } \\
\text { Masker }\end{array}$ \\
\hline
\end{tabular}

\section{F. Penghapusan Stopwords}

Pada tahap ini, semua kata-kata yang kurang memiliki makna atau tidak berpengaruh akan dimasukkan dalam stoplist yang berbahasa Indonesia.

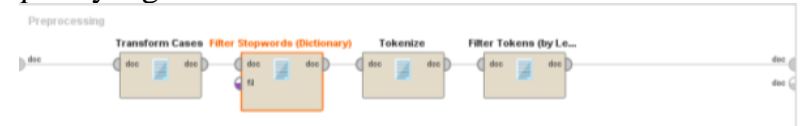

Gbr. 6 Sub-process Filter Stopwords

Stoplist dilakukan secara manual dalam Bahasa Indonesia dikarenakan dalam Rapidminer tidak ada kamus Bahasa Indonesia. Dan berikut adalah perbedaan sebelum dan sesudah dilakukan stopwords removal (penghapusan stopwords).

TABEl 6. PERbEDAAN SEBElum dAN SESUdAh PENGHAPUSAN STOPWORDS

\begin{tabular}{|l|l|}
\hline \multicolumn{1}{|c|}{$\begin{array}{c}\text { Sebelum penghapusan } \\
\text { stopwords }\end{array}$} & \multicolumn{1}{|c|}{$\begin{array}{c}\text { Setelah penghapusan } \\
\text { stopwords }\end{array}$} \\
\hline $\begin{array}{l}\text { cegah covid anggota polsek } \\
\text { laung tuhup ajak warga rajin } \\
\text { cuci tangan depan mako }\end{array}$ & $\begin{array}{l}\text { cegah covid ajak rajin } \\
\text { cuci tangan }\end{array}$ \\
\hline $\begin{array}{l}\text { tindak pelanggar protokol } \\
\text { kesehatan tidak pakai masker }\end{array}$ & $\begin{array}{l}\text { tindak pelanggar } \\
\text { protokol kesehatan } \\
\text { tidak pakai masker }\end{array}$ \\
\hline
\end{tabular}

\section{G. Tokenisasi}

Tahap berikutnya adalah tokenisasi yaitu mengubah sebuah kalimat menjadi beberapa bagian atau token. Langkah ini dilakukan agar memudahkan nantinya dalam pembobotan setiap kata yang ada.

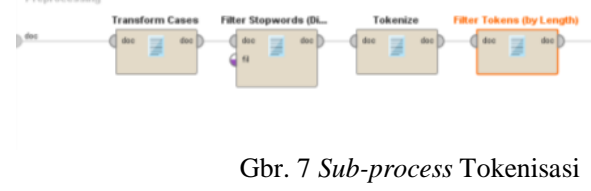

Berikut adalah sebelum dan sesudah tokenisasi.

TABEL 7. PERBEDAAN SEBELUM DAN SESUDAH TOKENISASI

Sebelum tokenisasi $\quad$ Setelah tokenisasi cegah covid ajak rajin cuci cegah - covid - ajak tangan 


\begin{tabular}{|l|l|}
\hline $\begin{array}{l}\text { tindak pelanggar protokol } \\
\text { kesehatan tidak pakai } \\
\text { masker }\end{array}$ & $\begin{array}{l}\text { tindak }- \text { pelanggar - } \\
\text { protokol }- \text { kesehatan }- \\
\text { tidak }- \text { pakai }- \text { masker }\end{array}$ \\
\hline
\end{tabular}

\section{H. Pembobotan Kata}

Langkah selanjutnya adalah pembobotan kata TF-IDF. Dalam pembobotan kata menggunakan metode $\mathrm{TF}$, digunakan TF murni dimana dihitung berapa banyak term yang ada pada teks, jika dalam satu teks muncul 2 kali maka teks tersebut akan memiliki skor 2. Dan berikut adalah contoh perhitungan manual TF-IDFnya:

Terdapat 816 teks opini Twitter dan kata "indonesia" terdapat pada 16 teks, maka pembobotan kata "indonesia" adalah:

$$
\log _{2}\left(\frac{816}{16}\right)=5,67
$$

Berikut adalah contoh pembobotan kata TF-IDF dari term "indonesia" pada teks tersebut:

$$
\frac{1}{11} \cdot \log _{2}\left(\frac{816}{16}\right)=0,515
$$

Langkah selanjutnya yaitu membagi data training dan data testing. Data ini dibagi dengan skala 80 data training: 20 data testing. Pembagian data training yaitu $80 \%$ dari 816 yaitu 653 teks dan data testing yaitu $20 \%$ dari 816 yaitu 163 teks.

\section{Membuat Sistem Klasifikasi}

Setelah dilakukan pembagian data training dan data testing selanjutnya yaitu perhitungan klasifikasi sistem dengan menggunakan metode naïve bayes classifier.

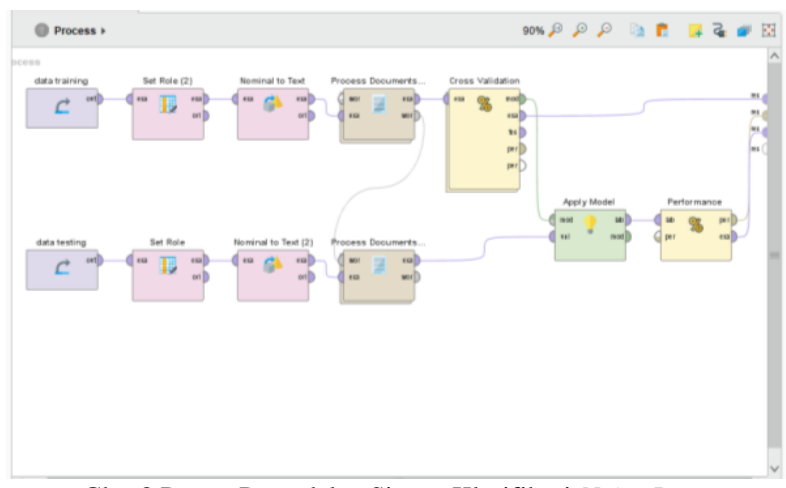

Gbr. 8 Proses Pemodelan Sistem Klasifikasi Naive Bayes

Pada gambar diatas terdapat proses pemodelan nä̈ve bayes secara otomatis menggunakan Rapidminer. Terdapat data training dan data testing yang sudah dibagi dan diRetrieve kedalam proses pemodelan. Kedua-duanya akan melalui operator Set Role dimana kolom Sentimen akan diberi rules sebagai "label". Setelah itu akan melewati operator "Nominal to Text" yang akan mengubah data yang betipe Nominal ke tipe Text. Keduanya juga akan melewati process document.

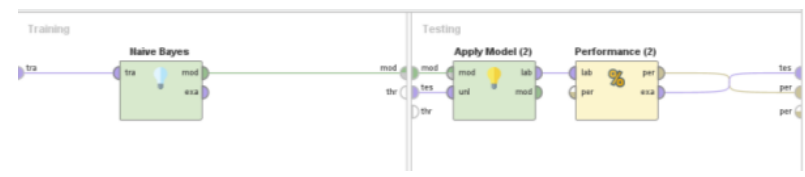

Gbr. 9 Proses Cross Validation
Setelah itu berdasarkan gambar diatas, Data training akan melewati Cross Validation untuk mengestimasi peforma dari model yang digunakan yaitu model klasifikasi Nä̈ve Bayes. Setelah data training melewati proses klasifikasi Nä̈ve Bayes, selanjutnya model klasifikasi akan diterapkan ke data testing. Lalu dihitung peformanya.

\section{J. Evaluasi Sistem}

Langkah berikutnya yang dilakukan setelah sistem klasifikasi dari data training telah dibuat yaitu pengujian terhadap sistem tersebut. Akan dilihat apakah sistem yang telah dibuat memiliki akurasi yang cukup tinggi sehingga layak untuk digunakan. Confusion matrix biasanya yang digunakan dalam pengujian akurasi ini, bukan hanya akurasi, tapi confusion matrix bisa menguji presisi, recall dan $f$ measure. Dalam confusion matrix terdapat 4 istilah, diantaranya True Positive, True Negative, False Positive dan False Negative. Berikut adalah tabel confusion matrixnya:

TABEL 8. HASIL CONFUSION MATRIX

\begin{tabular}{|c|c|c|c|}
\hline \multirow{4}{*}{ Predictive } & \multicolumn{3}{|c|}{ Actual } \\
\cline { 2 - 4 } & & Positif (1) & Negatif (0) \\
\cline { 2 - 4 } & Positif (1) & 90 & 13 \\
\cline { 2 - 4 } & Negatif (0) & 19 & 41 \\
\hline
\end{tabular}

Dari tabel diatas bisa terlihat true positive (TP) adalah semua data kategori positif yang berhasil terklasifikasi atau terprediksi positif yaitu sebanyak 90 data. True negative (TN) adalah semua data kategori negatif yang berhasil terklasifikasi atau terprediksi negatif yaitu sebanyak 41 data. Adapun false positive (FP) yang artinya semua data yang berkategori negatif tapi terklasifikasi atau terprediksi positif yaitu sebanyak 19 data. Sedangkan false negative (FN) yang artinya semua data yang berkategori positif tapi terklasifikasi atau terprediksi negatif yaitu sebanyak 13 data.

Akurasi yaitu jumlah semua data yang berhasil terklasifikasi dengan benar baik itu data positif maupun negatif dibagi dengan jumlah seluruh data, didapatkan hasil $87,38 \%$. Presisi adalah semua data true positif dibagi dengan semua data yang terklasifikasi positif, didapatkan hasil $87,38 \%$. Recall adalah banyaknya data yang berhasil terklasifikasi positif dengan benar dibagi dengan semua data yang terklasifikasi positif baik true positif maupun false negative, didapatkan hasil $82,57 \%$. Dan untuk perhitungan $f$-measure adalah dengan cara hasil kali dari presisi dan recall dibagi dengan hasil tambah presisi dan recall lalu dikali 2, dan didapatkan hasil $84,91 \%$

\section{K. Uji Coba Sistem}

Langkah selanjutnya adalah uji coba sistem dengan data yang lebih besar lagi untuk mengetahui bagaimana respon atau sentimen masyarakat terhadap kebijakan pemerintah New normal yang diantaranya pakai masker, jaga jarak dan cuci tangan. Data yang diambil adalah data crawling. 


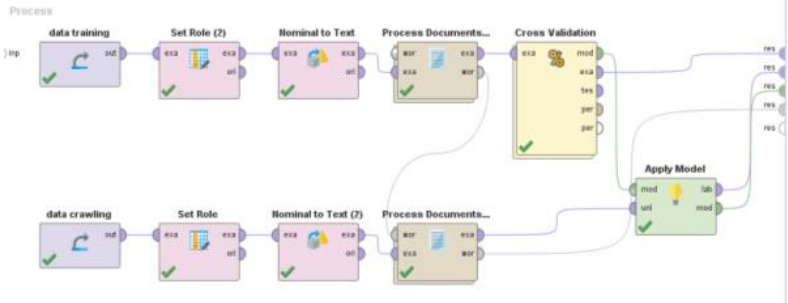

Gbr. 10 Proses Uji Coba Sistem

Dari hasil yang didapat terdapat 5194 teks yang diklasifikasikan ke dalam sentimen positif dan 2908 data yang terklasifikasi ke dalam sentimen negatif. Jadi untuk presentasi sentimen positif adalah sebagai berikut:

$$
\frac{5194}{8102} \times 100 \%=64,11 \%
$$

Sedangkan untuk presentasi sentimen negatif adalah:

$$
\frac{2908}{8102} \times 100 \%=35,89 \%
$$

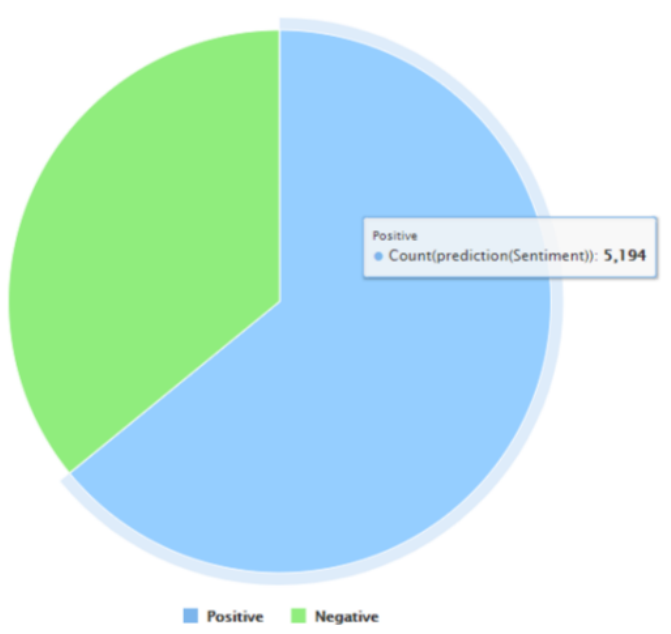

Gbr. 11 Diagram Hasil Analisis Sentimen

Dari gambar diatas, hasil analisis sentimen mengenai tanggapan masyarakat terhadap kebijakan pemerintah yaitu New normal pada masa pandemi covid-19 di Indonesia, dapat dilihat bahwa masih banyak tanggapan yang bersentimen positif daripada negatif.

L. Visualisasi Hasil Analisis

Visualisasi hasil dari analisis sentimen New normal di masa pandemi covid-19 ini, akan divisualisasikan dalam grafik wordcloud

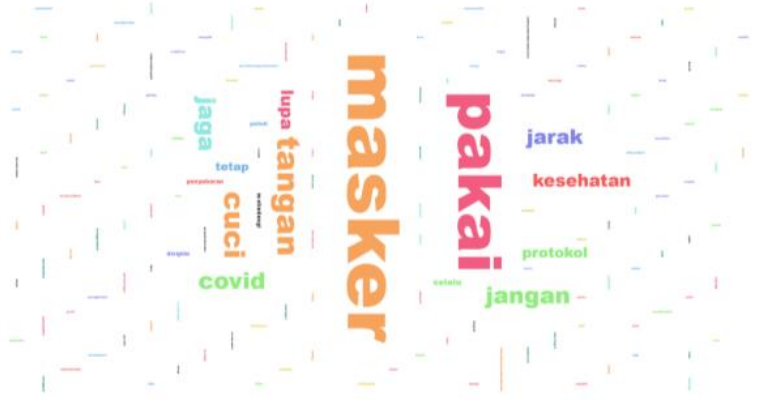

Gbr. 12 Wordcloud Sentimen Positif
Dari gambar diatas dapat dilihat kata yang memiliki ukuran yang besar merupakan kata-kata yang sering muncul atau memiliki term dengan jumlah yang cukup besar. Terdapat kata-kata; pakai masker, jaga jarak, jangan lupa, cuci tangan, protokol kesehatan, patuh, tetap, selalu, disiplin, patuh dsb. Kata-kata ini menunjukkan sentimen-sentimen positif dari tweet-tweet masyarakat, dimana yang kebanyakan merupakan pengingat-pengingat untuk tetap mematuhi protokol kesehatan.

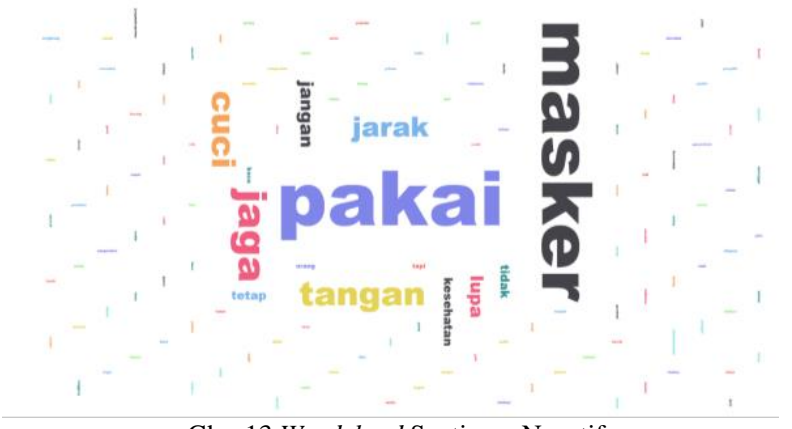

Gbr. 13 Wordcloud Sentimen Negatif

Gambar diatas menunjukkan ada persamaan seperti wordcloud sentiment positif, tapi tentunya ada yang membedakan yaitu kata "tidak" yang mau menunjukkan bahwa tweet-tweet ini bersentimen negatif. Nama-nama pemimpin pemerintah juga terdapat pada wordcloud ini tetapi frekuensi munculnya tidak terlalu besar. Para pengguna Twitter juga mengkritik bagaimana pemerintah menerapkan protokol kesehatan. Selain pemerintah tentunya tidak sedikit masyarakat disorot karena melanggar protokol kesehatan di masa pandemi covid-19.

\section{KESIMPULAN}

Dari hasil penelitian ini dapat disimpulkan pengklasifikasian sistem ini menggunakan metode Nä̈ve Bayes Classifier. Pengklasifikasian sentimen ke dalam kategori positif dan negatif dengan kasus bagaimana respon masyarakat terhadap kebijakan pemerintah yaitu new normal pada masa covid-19 di Indonesia, memiliki peforma tingkat akurasi $80,37 \%$, presisi $87,38 \%$, recall $82,57 \%$ dan f-measure $84,91 \%$.

Dari data yang sudah diambil (crawling) dari Twitter pada periode bulan Juni-Desember 2020 sebanyak 8102 teks Twitter dalam bentuk teks, didapatkan hasil bahwa masyarakat Indonesia merespon kebijakan pemerintah new normal dengan cukup baik dan positif dimana terdapat 5194 sentimen positif yang didalamnya terdapat ajakan untuk menaati kebijakan pemerintah dan perilaku-perilaku masyarakat yang mendukung kebijakan pemerintah new normal yang diantaranya adalah menjaga jarak, mencuci tangan dan memakai masker. Tapi ternyata tidak sedikit juga sentimen negatif yaitu sebanyak 2908 teks yang menunjukkan bahwa masih ada pelanggaran terhadap kebijakan pemerintah dalam hal ini menjaga jarak, mencuci tangan dan memakai masker. Kiranya penelitian ini bisa menjadi refrensi untuk penelitian di bidang text mining dan kedepannya penelitian ini dapat dikembangkan dengan memilih keyword yang lebih tepat dan dapat divisualisasikan dengan network graph atau dengan sistem 
berbasis web.

\section{DAFTAR PUSTAKA}

[1] CNN, "Status Pandemi WHO, Pemerintah Naikkan Kewaspadaan." 2020.

[2] CNN, "Jokowi Umumkan Dua WNI Positif Corona di Indonesia," Www.Cnnindonesia.Com. 2020.

[3] N. Ransi dan J. Nangi, "Text mining," vol. 3, no. 2, hal. 187194, 2017.

[4] B. W, I. Riski, K. Dwi, R. Nooraeni, T. Siahaan, dan Y. Dhea, "Analisis Text Mining dari Cuitan Twitter Mengenai Infrastruktur di Indonesia dengan Metode Klasifikasi Naïve Bayes," Eig. Math. J., vol. 1, no. 2, hal. 92, 2019.

[5] P. Pang dan L. Lee, "Opinion Mining and Sentiment Analysis, Foundations and Trends in Information Retrieval," vol. Vol. 2, no. No. 1-2, hal. 1-135, 2008.

[6] Z. T. H. Jordan, S. E., Hovet, S. E., Fung, I. C. H., Liang, H. $\mathrm{Fu}, \mathrm{K}$. W., \& Tse, "Using Twitter for public health surveillance from monitoring and prediction to public response.," vol. 4, no. 1, hal. 6, 2019.

[7] Adib Rifqi Setiawan, "Scientific Literacy Worksheets for Distance Learning in the Topic of Coronavirus 2019 (COVID19.," vol. 2019, no. February 2019, hal. 1-13, 2020

[8] Indonesian Health Ministry, "Kementerian Kesehatan Republik Indonesia," Kementerian Kesehatan RI. hal. 1, 2018.

[9] Kementrian Komunikasi dan Informatika, "Pengguna Internet di Indonesia 63 Juta Orang." 2020.

[10] M. S. Hadna, P. I. Santosa, dan W. W. Winarno, "Studi Literatur Tentang Perbandingan Metode Untuk Proses Analisis
Sentimen Di Twitter," Semin. Nas. Teknol. Inf. dan Komun. vol. 2016, no. Sentika, hal. 57-64, 2016.

M. Taheri, Sona and Mammadov, "Learning the naive Bayes classifier with optimization models," Int. J. Appl. Math. Comput. Sci., vol. 23, no. 4, hal. 787-795, 2013.

[12] R. A. de R, "Naive Bayes Classifier Teaching Material," in Material, 2006, hal. 1-9.

[13] Fachrul Rozy Saputra Rangkuti, “Analisis Sentimen Pengguna Twitter Terhadap Covid-19 Di Indonesia Menggunakan Metode Naïve Bayes Classifier(Nbc)," vol. 4, no. 2, 2018.

[14] K. Ganesan, A Brief Note on Stop Words for Text Mining and Retrieval. 2015.

[15] C. . Manning, P. Raghavan, dan H. Schutze, An Introduction to Information Retrieval. 2009.

[16] G. A. B, B. T. B. Adji, P. ., S.T., M.T., M.Eng, dan P. . Adhistya Erna Permanasari., S.T., M.T., "ANALISIS SENTIMEN CALON PRESIDEN INDONESIA 2014 DENGAN LIMA CLASS ATTRIBUTE,” Universitas Gadjah Mada, 2015.

[17] X. Huang dan Q. Wu, "Micro-blog commercial word extraction based on improved TF-IDF algorithm," in 2013 IEEE International Conference of IEEE Region 10 (TENCON 2013), 2013, hal. 1-5.

[18] F. Darwis Dzikril Hakimi, "Sistem Analisis Sentimen Publik Tentang Opini Pemilihan Kepala Daerah Jawa Timur 2018 Pada Dokumen Twitter Menggunakan Naive Bayes Classifier," Univ. Islam Negeri Sunan Ampel Surabaya, 2018.

[19] D. P. Artanti, A. Syukur, A. Prihandono, dan D. R. I. M. Setiadi, "Analisa Sentimen Untuk Penilaian Pelayanan Situs Belanja Online Menggunakan Algoritma Naïve Bayes," hal. 8 9, 2018. 